\title{
The use of soluble fibre for the management of chronic idiopathic large- bowel diarrhoea in police working dogs
}

\author{
J. C. Alves ${ }^{1,2^{*}} \mathbb{D}$, A. Santos ${ }^{1}$, P. Jorge ${ }^{1}$ and A. Pitães ${ }^{3}$
}

\begin{abstract}
Background: Chronic intermittent or persistent diarrhoea is a common condition in dogs and may be a reflex of gastrointestinal or non-gastrointestinal disorders. Besides diarrhoea, many athletes experience other gastrointestinal symptoms. Dietary fiber can help normalize colonic motility and transit time, support normal gastrointestinal microflora growth and provide fuel for colonocytes. This study aimed to evaluate dietary supplementation effectiveness with psyllium husk in police working dogs with chronic large-bowel diarrhoea. Twenty-two animals were selected. Concurrent conditions were ruled out through complete blood count and serum biochemistry. Fecal Clostridium and Salmonella were also screened. A soluble fiber, psyllium husk, was added to the diet at the dose of 4 tablespoons/day for 1 month. A daily log of fecal characteristics (type, frequency, and color) was maintained during the supplementation month and for an additional month, without supplementation.

Results: Response to treatment was classified as "very good" in 50\% of animals, "good" in $40 \%$ of animals, and "poor" in 10\% of cases. During the month of psyllium husk supplementation, defecation frequency decreased from 3.5 to 2.9 times a day, with $90 \%$ of animals showing consistent stools regularly and registering a mean increase of $2 \mathrm{~kg}$ in body weight. Beneficial effects were still observed during the second month, without psyllium husk supplementation.
\end{abstract}

Conclusion: Psyllium husk can be useful in the management of chronic large-bowel diarrhoea in working dogs, which exhibited lower defecation frequency, improved stool consistency, and gained weight. Effects were felt beyond the supplementation period. Alternative approaches for non-responsive cases need to be evaluated.

Keywords: Dog, Diarrhoea, Psyllium

\footnotetext{
* Correspondence: alves.jca@gnr.pt

${ }^{1}$ Guarda Nacional Republicana (Portuguese Gendarmerie), Lisbon, Portugal

${ }^{2}$ MED - Mediterranean Institute for Agriculture, Environment and

Development, Instituto de Investigação e Formação Avançada, Universidade

de Évora, Pólo da Mitra, Ap. 94, 7006-554 Évora, Portugal

Full list of author information is available at the end of the article
}

(c) The Author(s). 2021 Open Access This article is licensed under a Creative Commons Attribution 4.0 International License, which permits use, sharing, adaptation, distribution and reproduction in any medium or format, as long as you give appropriate credit to the original author(s) and the source, provide a link to the Creative Commons licence, and indicate if changes were made. The images or other third party material in this article are included in the article's Creative Commons licence, unless indicated otherwise in a credit line to the material. If material is not included in the article's Creative Commons licence and your intended use is not permitted by statutory regulation or exceeds the permitted use, you will need to obtain permission directly from the copyright holder. To view a copy of this licence, visit http://creativecommons.org/licenses/by/4.0/ The Creative Commons Public Domain Dedication waiver (http://creativecommons.org/publicdomain/zero/1.0/) applies to the data made available in this article, unless otherwise stated in a credit line to the data. 


\section{Background}

Chronic intermittent or persistent diarrhea is a common condition in dogs and may reflect gastrointestinal or non-gastrointestinal disorders [1]. Diarrhea is considered chronic if present for at least 2 days/week over at least 4 weeks [2, 3]. Chronic idiopathic diarrhoea is usually characterized by an increased frequency of defecation, usually by excess faecal mucus, and, to be classified as such, other conditions must be ruled out. Chronic largebowel diarrhoea is commonly caused by various factors, ranging from whipworms, dietary indiscretion, Clostridium perfringens enterotoxicosis, neoplasia, and irritable bowel disease [4-6].

While laboratory findings usually show normal complete blood counts and serum biochemistry, systemic diseases must be ruled out, and faecal examination should be conducted to dismiss whipworms, Salmonella spp. and Campylobacter spp. [2, 3]. Many patients show no physical abnormalities during the examination, but some may present with weight loss and poor body condition score [5].

In humans, runner's diarrhoea has also been described, which affects from 30 to $90 \%$ of athletes, with a toll on performance, mainly due to mechanical, ischemic, and nutritional factors [7]. Besides diarrhoea, many athletes experience gastrointestinal symptoms, from nausea, cramping, and bloating [8]. Interestingly, this phenomenon, which affects athletes other than runners, seems to occur more at rest (after exercise) than during exercise itself [9]. A similar phenomenon may be present in working dogs.

Dietary fiber can help normalize colonic motility and transit time, support normal gastrointestinal microflora growth and provide fuel for colonocytes. Soluble fibers can be added to a normal diet to improve the faeces' consistency, as they have great water-holding capacities, forming gels in water. They can also influence the large intestine microflora constitution and increase colonic weight and surface area, increasing absorptive capacity $[5,10,11]$. This microflora also ferments soluble fiber and produces volatile fatty acids that promote colonocyte regeneration and may improve recovery from diarrhoea [12-14]. Psyllium husk is a mixed fiber source, commonly used in commercial pet foods and supplementation outside diet, and is particularly useful in working dogs with stress/ working diarrhoea $[2,11,15]$. Weekly recording of body weight, body condition score (BCS), and stool evaluations are useful for assessing patients with chronic colitis [5].

This study aimed to evaluate if the supplementation with psyllium husk would help manage chronic idiopathic large-bowl diarrhoea in police working dogs.

\section{Results}

The sample included 22 animals, of both sexes (all intact, 17 males and 5 females), with a mean age of $4 \pm 1.4$ years, bodyweight of $27.6 \pm 5.2 \mathrm{~kg}$, and a body condition score of 4/9. Four breeds were represented: Belgian Malinois Shepherd Dogs (BM, $n=12$ ), German Shepherd Dogs (GSD, $n=9$ ), and Dutch Shepherd Dog (DSD, $n=1$ ). Of the animals enrolled in the study, no abnormalities were observed during the physical examination, and $\mathrm{CBC}$ results and serum biochemistry were also normal in all animals. Overall $\mathrm{CBC}$ results and serum biochemistry registered can be observed in Table 1.

Faecal flotation and screenings were also negative. All animals showed continuous diarrhoea and increased defecation frequency, with a mean value of 3.5 times a day (range 3-6 times a day). Also, 37.5\% of cases presented permanent decreased faecal consistency. For the remaining animals, faecal consistency showed a decreasing tendency with subsequent defecations. All animals presented faecal mucus. As a rule, animals included in this study can be described as extremely active, both during work and when kennelled, with very high drive. As they are housed in a facility with many dogs, environmental stress factors are also present.

Response to treatment was classified as "very good" in $50 \%$ of animals, "good" in $40 \%$ of animals, and "poor" in $10 \%$ of cases. During the month of psyllium supplementation, defecation frequency decreased from 3.5 to 2.9 times a day $(p<0.01)$, with $90 \%$ of animals showing consistent stool regularly (scores $2-5$ in the Bristol stool chart). An increase in faecal bulk was observed. A mean increase of $2 \mathrm{~kg}$ in body weight was observed (range 0.4$4.8 \mathrm{~kg}, p=0.01$ ). During the second month of monitoring, without psyllium supplementation, defecation frequency showed a very mild increase to a mean value of 3.0 times a day, with $90 \%$ of animals still exhibiting consistent stools, with only sporadic episodes of diarrhoea. Defecation frequency returned to values near initial evaluation only in week 3 without psyllium supplementation $(p=0.06)$. The overall distribution of the relative frequency of faecal scores can be observed in Table 2. During this period, response to treatment was still classified as very good in $50 \%$ of animals, good in $40 \%$ of animals, and poor in $10 \%$ of cases. A mean increase of $0.6 \mathrm{~kg}$ in body weight was still observed (range $-0.7-2.9 \mathrm{~kg}, \quad p=0.06$ ). No additional medication was administered to any of the dogs enrolled.

\section{Discussion}

In this study, daily supplementation with psyllium husk improved clinical signs in police working dogs with chronic diarrhoea, decreasing defecation frequency and improving stool consistency. Treated animals also exhibited a weight gain. These beneficial effects were still felt in the second month of monitoring without psyllium supplementation for most animals.

In a previous study regarding the management of chronic large-bowel diarrhoea laboratory results are usually normal, with only mild abnormalities identified 
Table 1 Results of complete blood count results and serum biochemistry registered

\begin{tabular}{|c|c|c|c|}
\hline Parameter & Mean Value & SD & Reference Value \\
\hline$\overline{\mathrm{RBC}\left(\times 10^{12} / \mathrm{L}\right)}$ & 6.84 & 0.92 & $5.5-8.5$ \\
\hline Hemoglobin (g/L) & 153.9 & 0.00 & $120-180$ \\
\hline Hematocrit (Proportion of 1.0) & 0.46 & 0.06 & $0.37-0.55$ \\
\hline Total white blood cells $\left(\times 10^{9} / \mathrm{L}\right)$ & 9.77 & 3.93 & $6.0-17.0$ \\
\hline Lymphocytes $\left(\times 10^{9} / \mathrm{L}\right)$ & 2.06 & 1.02 & $1.0-4.8$ \\
\hline Monocytes $\left(\times 10^{9} / \mathrm{L}\right)$ & 0.69 & 0.39 & $0.2-2$ \\
\hline Neutrophils $\left(\times 10^{9} / \mathrm{L}\right)$ & 6.68 & 0.36 & $3.0-11.8$ \\
\hline Eosinophils $\left(\times 10^{9} / \mathrm{L}\right)$ & 0.31 & 0.36 & $0.1-1.3$ \\
\hline Basophils $\left(\times 10^{9} / \mathrm{L}\right)$ & 0.03 & 0.01 & $0.0-0.5$ \\
\hline Platelets $\left(\times 10^{9} / \mathrm{L}\right)$ & 295.94 & 59.84 & $200-500$ \\
\hline Urea $(\mathrm{mmol} / \mathrm{L})$ & 12.89 & 5.03 & $5.34-14.28$ \\
\hline Creatinine $(\mu \mathrm{mol} / \mathrm{L})$ & 73.37 & 30.06 & $35.36-123.76$ \\
\hline AST $(\mu k a t / L)$ & 0.71 & 0.26 & $0.17-0.67$ \\
\hline ALT ( $\mu k a t / L)$ & 5497.80 & 2684.95 & $1122.0-7854.0$ \\
\hline Bilirrubine $(\mu \mathrm{mol} / \mathrm{L})$ & 1.03 & 0.68 & $1.71-5.13$ \\
\hline Amylase ( $\mu$ kat/L) & 9.89 & 4.99 & $3.34-21.54$ \\
\hline Lipase $(\mu k a t / L)$ & 0.56 & 0.19 & $<8.35$ \\
\hline PT (g/L) & 588.68 & 3,80 & $55-75$ \\
\hline$A L B(g / L)$ & 30.06 & 2.88 & $23-31$ \\
\hline Colesterol (mmol/L) & 4.79 & 0.98 & $2.85-8.13$ \\
\hline $\mathrm{Ca}^{2+}(\mathrm{mmol} / \mathrm{L})$ & 2.28 & 0.27 & $2.23-0.28$ \\
\hline $\mathrm{Na}^{+}(\mathrm{mmol} / \mathrm{L})$ & 145.41 & 1.73 & $135-146$ \\
\hline $\mathrm{K}^{+}(\mathrm{mmol} / \mathrm{L})$ & 5,02 & 0.4 & $3.3-5$ \\
\hline $\mathrm{Cl}^{-}(\mathrm{mmol} / \mathrm{L})$ & 111.91 & 2.66 & $94-113$ \\
\hline $\mathrm{P}(\mathrm{mmol} / \mathrm{L})$ & 4,92 & 2.79 & $2.5-6$ \\
\hline
\end{tabular}

in $37.8 \%$ of cases: high ALP, a slight increase in ALT, slight hypoalbuminemia, lymphocytosis, eosinophilia, lymphopenia, and slight neutropenia [2]. Other reports point out that working dogs, in particular, typically have higher values of ALP, which, together with lipase, can help determine the presence of pancreatitis in dogs [16-19]. A lack of recovery and the chronicity of the condition is frequently associated with anaemia and severe hypoalbuminemia [1]. Our results are in line with these reports, as no abnormalities were observed during the physical examination, and $\mathrm{CBC}$ scores and serum biochemistry were also normal.

Various personality traits and stressful factors have been described and associated with chronic large-bowel diarrhoea in dogs. Dogs with chronic large-bowel diarrhoea have been described as nervous and high-strung, accounting for $37.8 \%$ of cases in a review study [2]. This high-strung characteristic can describe all of the dogs

Table 2 Distribution of relative frequency of faecal scores according to the Bristol stool chart with and after supplementation with soluble fiber

\begin{tabular}{|c|c|c|c|c|c|c|c|c|c|c|c|}
\hline \multirow[t]{2}{*}{ Score } & \multirow[t]{2}{*}{ TO } & \multicolumn{5}{|c|}{ 1st month } & \multicolumn{5}{|c|}{ 2nd month } \\
\hline & & week 1 & week 2 & week 3 & week 4 & week 5 & week 1 & week 2 & week 3 & week 4 & week 5 \\
\hline 1 & 0,0 & 0,0 & 0,0 & 0,0 & 0,0 & 0,0 & 0,0 & 0,0 & 0,0 & 0,0 & 0,0 \\
\hline 2 & 0,0 & 0,0 & 28,6 & 28,6 & 40,0 & 28,6 & 25,7 & 25,7 & 31,4 & 25,7 & 25,7 \\
\hline 3 & 14,3 & 37,1 & 31,4 & 28,6 & 20,0 & 25,7 & 28,6 & 42,9 & 31,4 & 34,3 & 37,1 \\
\hline 4 & 28,6 & 28,6 & 5,7 & 22,9 & 14,3 & 31,4 & 22,9 & 20,0 & 8,6 & 11,4 & 11,4 \\
\hline 5 & 14,3 & 5,7 & 31,4 & 14,3 & 20,0 & 14,3 & 20,0 & 11,4 & 25,7 & 20,0 & 17,1 \\
\hline 6 & 42,9 & 28,6 & 2,9 & 5,7 & 5,7 & 0,0 & 2,9 & 0,0 & 2,9 & 8,6 & 8,6 \\
\hline 7 & 0,0 & 0,0 & 0,0 & 0,0 & 0,0 & 0,0 & 0,0 & 0,0 & 0,0 & 0,0 & 0,0 \\
\hline
\end{tabular}


included in this study. In addition to breed-specific traits, such as the case of Belgian Malinois, these dogs present very high drives besides being very active when kennelled. A stressful event often initiates clinical signs, a phenomenon often observed in working dogs $[2,6]$, in contrast to what is observed in sedentary dogs, where exercise can help with chronic diarrhoea [20]. Training and active work are sources of multiple events that can induce stress, thus providing various opportunities to trigger clinical signs. Besides, exercise can also offset a phenomenon similar to runner's diarrhoea in humans. Decreasing kennel stress and better preparing working animals from a very young age to cope with stress is warranted and may help reduce this problem. Preparing future working dogs for predictable challenges from a very young age has recently been a topic of interest [21, 22]. It may set the stage for study work analysing its effect on this type of diarrhoea.

Adding fiber, and consequently, short-chain fatty acids can help to protect from colitis [6]. It may be an interesting supplementation to regularly maintain working dogs due to their proneness to develop colitis. Still, some difficulties may arise when administering it to dogs. The psyllium presentation used in this study was a powder, and the amount administered to large dogs may decrease appetence and overall palatability. Some cases may also require medication introduction, such as antibiotics (oxytetracycline, metronidazole, or tylosin) [23]. Metronidazole, in particular, is also effective in reducing chronic intestinal inflammation and colitis [24]. No medication was used for any of the dogs enrolled. Probiotics have also been suggested for human athletes, as they can colonize the gastrointestinal tract, adding benefits to health in general, as changes in immune and inflammatory markers in humans [8]. This approach may be of interest to working dogs, so further studies are required to test this possibility.

This study presents some limitations, namely its sample size, the lack of a control group, and the fact that it was not double-blinded. Since the present study showed positive results in managing chronic large-bowel diarrhoea, future studies should enroll a larger number of animals and a control group.

\section{Conclusions}

This study described the effect of psyllium husk in managing chronic large-bowel diarrhoea, with patients showing decreasing defecation frequency, improved stool consistency, and weight gain. Beneficial effects were felt beyond the period of supplementation for most animals. Further studies on alternative approaches to the management of non-responsive cases are required.

\section{Methods}

The study protocol was approved by the ethical review committee of the University of Évora (Órgão Responsável pelo Bem-estar dos Animais da Universidade de Évora). The study took place between January and June 2020. Animals were signaled from the population of police working dogs of the Guarda Nacional Republicana (Portuguese Gendarmerie Canine Unit), based on history, trainer complaints, physical (body weight, body condition score, increased frequency of defecation, soft or liquid stool, excess faecal mucus, slight weight loss, difficulty maintaining an adequate body condition score, continuously or intermittently) and laboratory examination consistent with chronic idiopathic large-bowl diarrhoea. All applicable international, national, and institutional guidelines for the care and use of animals were followed. To be included in the study, animals should be active police working dogs, have a bodyweight $\geq 15 \mathrm{~kg}$, and age $>2$ years. Patients with other illnesses (ruled out through physical examination, complete blood count, and serum biochemistry profile) and on any other treatment protocol were excluded.

Blood samples were collected for the assessment of complete blood count, albumin (ALB), total protein (TP), urea, creatinine (Crea), alkaline phosphatase (ALP), alanine aminotransferase (ALT), bilirubin, cholesterol $(\mathrm{Chol})$, sodium $(\mathrm{Na}+)$, potassium $(\mathrm{K}+)$, chloride $\left(\mathrm{Cl}^{-}\right)$, calcium $\left(\mathrm{Ca}^{2+}\right)$ and phosphorus (P) (sent to the lab and analysed immediately after collection). Faecal samples were also obtained, and faecal flotations were performed (zinc sulfate faecal flotation). Faecal Clostridium (SBA), clostridial enterotoxin (ELISA), and Salmonella media screening (blood agar, MacConkey's agar, Hektoen enteric agar, or Campy BAP, then placed in selenite enrichment) were also performed.

All dogs received soluble fiber, psyllium husk, commercially available as a powder, at the dose of 4 tablespoons/ day for 1 month $[2,15]$. According to the Bristol stool chart, daily registration of faecal characteristics (type, frequency, and color) was maintained during the supplementation month and for an additional month. The same researcher conducted all observations. Animals were weighed weekly. A very good response was considered if faeces were usually normal, with only occasional diarrhea responses, but at a lower frequency than before treatment. The response was deemed good if normal faeces predominated, with common diarrhea episodes, but frequently and less severe. In a poor response, the diarrhoea's frequency and severity were unaffected by fiber supplementation [2]. The need for any drug to manage diarrhoea was registered.

Each week's faecal scoring and frequency were compared to the initial evaluation with the Wilcoxon Signed Rank test. The paired-samples t-test was used to compare the body weight of each week with the initial value. A $p<0.05$ value was set. 


\section{Abbreviations}

ALB: Albumin; ALP: Alkaline phosphatase; ALT: Alanine aminotransferase; $\mathrm{Ca}^{2+}$ : Calcium; Chol: Cholesterol; $\mathrm{Cl}^{-}$: Chloride; Crea: Creatinine; $\mathrm{K}^{+}$: Potassium; $\mathrm{Na}^{+}$: Sodium; TP: Total protein; P: Phosphorus

\section{Acknowledgments}

Not applicable.

\section{Authors' contributions}

JCA designed the protocol, conducted treatments, and prepared the manuscript. PJ and AS selected patients and conducted treatments. AP revised the protocol and prepared the manuscript. All authors have read and approved the manuscript.

\section{Funding}

The authors of this paper do not have any financial or personal relationship with other persons or organizations that could inappropriately influence or bias the content of this paper.

\section{Availability of data and materials}

The data that support the findings of this study are available from the Guarda Nacional Republicana, but restrictions apply to the availability of these data, which were used under license for the current study, and so are not publicly available. Data are however available from the authors upon reasonable request and with permission of Guarda Nacional Republicana

\section{Declarations}

Ethics approval and consent to participate

All applicable international, national, and institutional guidelines for the care and use of animals were followed. The study protocol was approved by the ethical review committee of the University of Évora (Órgão Responsável pelo Bem-estar dos Animais da Universidade de Évora). Written, informed consent was obtained from the Institution responsible for all the animals (Guarda Nacional Republicana, Portuguese Gendarmerie).

\section{Consent for publication}

Not applicable.

\section{Competing interests}

The authors have no competing interests to declare.

\section{Author details}

'Guarda Nacional Republicana (Portuguese Gendarmerie), Lisbon, Portugal. ${ }^{2}$ MED - Mediterranean Institute for Agriculture, Environment and Development, Instituto de Investigação e Formação Avançada, Universidade de Évora, Pólo da Mitra, Ap. 94, 7006-554 Évora, Portugal. ${ }^{3}$ Vale Referrals, the Animal Hospital, Stinchcombe, Dursley, Gloucestershire GL116AJ, UK.

Received: 14 August 2020 Accepted: 19 February 2021 Published online: 02 March 2021

\section{References}

1. Volkmann M, Steiner JM, Fosgate GT, Zentek J, Hartmann S, Kohn B. Chronic diarrhea in dogs - retrospective study in 136 cases. J Vet Intern Med. 2017; 31:1043-55.

2. Leib MS. Treatment of chronic idiopathic large-bowel diarrhea in dogs with a highly digestible diet and soluble Fiber. J Vet Intern Med. 2000;14:27-32.

3. Lecoindre P, Gaschen FP. Chronic idiopathic large bowel diarrhea in the dog. Vet Clin North Am - Small Anim Pract. 2011:41:447-56.

4. Leib MS, Codner EC, Monroe W. A diagnostic approach to chronic large bowel diarrhea in dogs. Vet Med. 1991;86:892-9.

5. Davenport D, Remillard R, Carroll M. Large Bowel Diarrhea: Colitis. In: Small Animal Clinical Nutrition. 5th ed; 2010. p. 1101-9.

6. Simpson JW. Diet and large intestinal disease in dogs and cats. J Nutr. 1998; 128(12 Suppl):2717S-22S. https://doi.org/10.1093/jn/128.12.2717S.

7. de Oliveira EP. Runner's diarrhea. Curr Opin Gastroenterol. 2017:33:41-6. https://doi.org/10.1097/MOG.0000000000000322.

8. Pyne DB, West NP, Cox AJ, Cripps AW. Probiotics supplementation for athletes - clinical and physiological effects. Eur J Sport Sci. 2015;15:63-72.
9. Peters HPF, Bos M, Seebregts L, Akkermans LMA, Berge Henegouwen GP, Bol $E$, et al. Gastrointestinal symptoms in long-distance runners, cyclists, and triathletes: prevalence, medication, and etiology. Am J Gastroenterol. 1999; 94:1570-81. https://doi.org/10.1111/j.1572-0241.1999.01147.x.

10. Dimski DS, Buffington CA. Dietary fiber in small animal therapeutics. J Am Vet Med Assoc. 1991;199:1142-6 http://www.ncbi.nlm.nih.gov/pubmed/1 661278.

11. Linder D. Featuring Fiber: Understanding Types of Fiber \& Clinical Uses. TVP J. 2017:7:69-74

12. Wakshlag J, Simpson K, Struble A, Dowd S. Negative fecal characteristics are associated with $\mathrm{pH}$ and feca flora alterations during dietary changes in dogs. Int J Appl Res Vet Med. 2011;9:278-83.

13. Gagné JW, Wakshlag JJ, Simpson KW, Dowd SE, Latchman S, Brown DA et al. Effects of a synbiotic on fecal quality, short-chain fatty acid concentrations, and the microbiome of healthy sled dogs. BMC Vet Res. 2013;9:246. https://doi.org/10.1186/1746-6148-9-246.

14. Whelan K, Schneider SM. Mechanisms, prevention, and management of diarrhea in enteral nutrition. Curr Opin Gastroenterol. 2011;27:152-9. https:// doi.org/10.1097/MOG.0b013e32834353cb.

15. Wakshlag JJJ. The role of nutrition in canine performance and rehabilitation. In: Zink C, Van Dyke J, editors. Canine sports medicine and rehabilitation. 2nd ed. Hoboken: John Wiley \& Sons, Inc; 2018. p. 72-95.

16. Tarpley H, Bounous D. Digestive System. In: Duncan \& Prasse's veterinary laboratory medicine : clinical pathology. 5th ed; 2011. p. 231-52.

17. Kerr M. Clinical Enzymology - Plasma Enzymes in Diagnosis. In: Veterinary Laboratory Medicine. 2nd ed; 2012. p. 135-48.

18. Yuki M, Hirano T, Nagata N, Kitano S, Imataka K, Tawada R, et al. Clinical utility of diagnostic laboratory tests in dogs with acute pancreatitis: a retrospective investigation in a primary care hospital. J Vet Intern Med. 2016;30:116-22. https://doi.org/10.1111/jvim.13660.

19. Chang Y-M, Hadox E, Szladovits B, Garden OA. Serum biochemical phenotypes in the domestic dog. PLoS One. 2016;11:e0149650. https://doi. org/10.1371/journal.pone.0149650.

20. Huang H-PP, Lien Y-HH. Effects of a structured exercise programme in sedentary dogs with chronic diarrhoea. Vet Rec. 2017;180:224. https://doi. org/10.1136/vr.103902.

21. Alves JC, Santos A, Lopes B, Jorge P. Effect of auditory stimulation during early development in puppy testing of future police working dogs. Top Companion Anim Med. 2018:33:100-4. https://doi.org/10.1053/j.tcam.2018.08.004.

22. Lopes B, Alves J, Santos A, Pereira GDG. Effect of a stimulating environment during the socialization period on the performance of adult police working dogs. J Vet Behav. 2015;10:199-203. https://doi.org/10.1016/j.jveb.2015.01.002

23. Hall EJ. Antibiotic-responsive diarrhea in small animals. Vet Clin North Am Small Anim Pract. 2011:41:273-86. https://doi.org/10.1016/j.cvsm.2010.12.004.

24. Marks SL. Editorial: small intestinal bacterial overgrowth in dogs- less common than you think? J Vet Intern Med. 2003;17:5-7. https://doi.org/1 0.1111/j.1939-1676.2003.tb01317.x.

\section{Publisher's Note}

Springer Nature remains neutral with regard to jurisdictional claims in published maps and institutional affiliations.

\section{Ready to submit your research? Choose BMC and benefit from:}

- fast, convenient online submission

- thorough peer review by experienced researchers in your field

- rapid publication on acceptance

- support for research data, including large and complex data types

- gold Open Access which fosters wider collaboration and increased citations

- maximum visibility for your research: over $100 \mathrm{M}$ website views per year

At BMC, research is always in progress.

Learn more biomedcentral.com/submissions 